\title{
SUMBER SOSIOLOGIS PANCASILA SEBAGAI DASAR NEGARA
}

\author{
LENSI PUTRI UTAMI \\ Lensiputriutami587@gmail.com \\ 20220057 \\ STIE AKBP “KBP" PADANG
}

\section{A. PENDAHULUAN}

Sosiologi dipahami sebagai ilmu tentang kehidupan antarmanusia. Di Dalamnya mengkaji, antara lain, susunan dan pola kehidupan sosial dari Berbagai golongan dan kelompok masyarakat,juga mengkaji masalah masalah sosial, perubahan dan pembaharuan dalam masyarakat. Menegaskan bahwa dalam perspektif sosiologi, suatu masyarakat pada suatu waktu dan Tempat memiliki nila-nilai yang tertentu. Melalui pendekatan sosiologis ini pula, anda Diharapkan dapat mengkaji struktur sosial, proses sosial, termasuk perubahanperubahan sosial, dan masalah-masalah sosial yang patut disikapi secara arif dengan Menggunakan standar nilai-nilai yang mengacu kepada nilai-nilai Pancasila.Berbeda dengan bangsa-bangsa lain, Bangsa Indonesia mendasarkan Pandangan hidupnya dalam bermasyarakat, berbangsa, dan bernegara pada suatu asas Kultural yang dimiliki dan melekat pada bangsa, dan bernegara pada suatu asas Kultural yang dimiliki dan melekat pada bangsa itu sendiri, nilai-nilai kenegaraan dan Kemasyarakatan yang terkandung dalam sila-sila Pancasila bukan hanya hasil Konseptual seseorang saja, melainkan juga hasil karya besar Bangsa Indonesia sendiri Melalui proses refleksi filosofis para pendiri negara. Bung Karno Menegaskan bahwa nilai-nilai Pancasila digali dari bumi pertiwi Indonesia. Dengan Kata lain, nilai-nilai Pancasila berasal dari kehidupan sosiologis masyarakat Indonesia. 
Pancasila sebagai dasar nilai pengembangan ilmu, yang meliputi nilai ketuhanan, kemanusian, persatuan, Kerakyatan dan keadilan. Ebagai dasar pengembangan ilmu. Pengembangan Ilmu pengetahuan dan teknologi (iptek) dewasa ini, mencapai kemajuan pesat Sehingga peradaban manusia mengalami perubahan yang luar biasa. Pengembangan iptek tidak dapat terlepas dari situasi yang melingkupinya Artinya iptek selalu berkembang dalam suatu ruang budaya. Perkembangan Iptek pada gilirannya bersentuhan dengan nilai-nilai budaya dan agama Sehingga di satu pihak dibutuhkan semangat objektivitas, di pihak lain iptek Perlu mempertimbangkan nilai-nilai budaya dan agama dalam Pengembangannya agar tidak merugikan umat manusia. Relasi antara iptek Dan nilai budaya serta agama akan dapat ditandai dengan beberapa Kemungkinan sebagai berikut. Pertama; iptek yang gayut dengan nilai budaya Dan agama sehingga pengembangan iptek harus senantiasa didasarkan atas Sikap humanreligius. Kedua; iptek yang lepas sama sekali dari norma budaya Dan agama sehingga terjadi sekularisasi yang berakibat pada kemajuan iptek Tanpa dikawal dan diwarnai nilai humanreligius. Hal ini terjadi karena Sekelompok ilmuwan yang meyakini bahwa iptek memiliki hukum-hukum Sendiri yang lepas dan tidak perlu diintervensi nilai-nilai dari luar. Ketiga; iptek Yang menempatkan nilai agama dan budaya sebagai mitra dialog di saat Diperlukan. Dalam hal ini ada sebagian ilmuwan yang beranggapan bahwa Iptek memang memiliki hukum tersendiri (faktor internal), tetapi di pihak lain Diperlukan faktor eksternal (budaya, ideologi, dan agama) untuk bertukar Pikiran, meskipun tidak dalam arti saling bergantung secara ketat. Relasi yang paling ideal antara iptek dan nilai budaya serta agama tentu Terletak pada fenomen pertama, meskipun hal tersebut belum dapat Berlangsung secara optimal, mengingat keragaman agama dan budaya di Indonesia itu sendiri. Keragaman tersebut, di satu pihak dapat menjadi Kekayaan, tetapi di pihak lain dapat memicu terjadinya konflik. Oleh karena itu, Diperlukan sikap inklusif dan toleran di masyarakat untuk mencegah Timbulnya konflik di masyarakat. Untuk itu, komunikasi yang terbuka dan Egaliter diperlukan dalam kehidupan 
bermasyarakat, berbangsa, dan Bernegara. Fenomena kedua yang menempatkan pengembangan iptek di luar Nilai budaya dan agama, jelas bercorak positivistis. Kelompok ilmuwan dalam Fenomena kedua ini menganggap intervensi faktor eksternal justru dapat Mengganggu objektivitas ilmiah. Fenomena ketiga yang menempatkan nilai Budaya dan agama sebagai mitra dialog merupakan sintesis yang lebih Memadai dan realistis untuk diterapkan dalam pengembangan iptek di Indonesia. Karena iptek yang berkembang di ruang hampa nilai justru akan Menjadi bumerang yang membahayakan aspek kemanusiaan.

\section{B. PEMBAHASAN}

\section{SUMBER SOSIOLOGIS PANCASILA SEBAGAI DASAR NEGARA}

- Pancasila Sebagai Dasar Negara

Pancasila sebagai dasar negara artinya ideologi Pancasila menjadi landasan, panduan dan pedoman resmi kehidupan berbangsa dan bernegara. Indonesia, sejak pertama kali didirikan telah menetapkan Pancasila sebagai dasar negara sekaligus ideologi negara. Kita, rakyat Indonesia sudah selayaknya menempatkan Pancasila di posisi yang luhur dan mulia, namun bukan berarti menuhankannya.

Istilah Pancasila sudah eksis jauh sebelum negara Indonesia berdiri. Sejak zaman Majapahit, yaitu sekitar abad 14 masehi, istilah Pancasila sudah dikenal. Berasal dari Bahasa Sansekerta, Pancasila merupakan perpaduan istilah panca dan sila. Panca artinya lima, dan sila artinya batu sendi, maksudnya adalah prinsip dasar.

- Sejarah LahirNya Pancasila

Naskah kuno zaman Majapahit bernama Nagara Kertagama karangan Empu Tantular telah memuat istilah Pancasila yang berarti lima prinsip dasar. Naskah tersebut ditulis sekitar abad 14. Enam abad kemudian ketika sedang berada di pengasingan Flores, Bung Karno 
mengklaim diri mendapat ilham tentang nilai-nilai dasar yang layak menjadi ideologi Indonesia. Kelima nilai dasar tersebut dinamakan Pancasila.

Secara formal, Bung Karno menyampaikan usulan tentang Pancasila sebagai dasar negara Indonesia pada sidang BPUPKI 1 Juni 1945. Sidang BPUPKI sendiri berlangsung pada 29 Mei - 1 Juni 1945. Sampai di sini saya menganjurkan pada pembaca blog ini untuk tidak memikirkan Pancasila yang sudah jadi sekarang ini. Pancasila pada saat itu masih berupa rumusan lima nilai yang letaknya masih dirumuskan. Misal, Pada 29 Mei, Muh. Yamin menyampaikan Pancasila terdiri dari lima nilai sebagai berikut:

1. Perikebangsaan

2. Perikemanusiaan

3. Periketuhanan

4. Perikerakyatan

5. Kesejahteraan rakyat

Lalu pada tanggal 1 Juni 1945, Bung Karno mengusulkan lima asas Pancasila sebagai berikut:
a. Kebangsaan Indonesia
b. Internasionalisme atau perikemanusiaan
c. Mufakat atau demokrasi
d. Kesejahteraan sosial
e. Ketuhanan yang berkebudayaan

Bila menyimak paparan di atas, kita temukan bahwa rumusan Pancasila belum rampung dan masih diperdebatkan. Pada 22 Juni 1945 dibentuklah Panitia Sembilan yang diketuai oleh Bung Karno. Panitia Sembilan ini menghasilkan Piagam Jakarta yang didalamnya terdapat rumusan Pancasila sebagai berikut:

i. Ketuhanan dengan kewajiban menjalankan syariat Islam bagi pemelukpemeluknya 
ii. Kemanusiaan yang adil dan beradab

iii. Persatuan Indonesia

iv. Kerakyatan yang dipimpin oleh hikmat dan kebijksanaan dalam permusyawaratan/perwakilan

v. Keadilan sosial bagi seluruh rakyat Indonesia

Bila kita simak Pancasila hasil Piagam Jakarta, perbedaan yang terdapat pada Pancasila tersebut dengan versi sekarang adalah sila pertama. Penghapusan tujuh kata dan penggantian dengan bunyi Ketuhanan Yang Maha Esa di sila pertama disahkan pada 18 Agustus 1945 pada sidang PPKI yang diketuai oleh Bung Karno. Rumusan Pancasila tersebut terkandung dalam UUD 1945 yang berbunyi:

1. Ketuhanan Yang Maha Esa

2. Kemanusiaan yang adil dan beradab

3. Persatuan Indonesia

4. Kerakyatan yang dipimpin oleh hikmat dan kebijksanaan dalam permusyawaratan/perwakilan

5. Keadilan sosial bagi seluruh rakyat Indonesia

Penetapan Pancasila sebagai dasar negara tidak selesai hanya dengan persetujuan anggota PPKI. Diperlukan pengakuan konstitusional yang sekaligus menjadi kekuatan hukum Pancasila selanjutnya.

- Dasar Hukum Penetapan Pancasila Sebagai Dasar Negara

Diawal kita sudah mengetahui bahwa sidang PPKI pada 18 Agustus 1945 dan UUD 1945 sebagai dua diantara berbagai macam dasar hukum penetapan Pancasila sebagai dasar negara. Dasar hukum lainnya yang menguatkan Pancasila antara lain:

○ Pembukaan UUD 1945 alenia ke-4 yang menyatakan bahwa pembentukan pemerintahan negara Indonesia dilanasi oleh Pancasila. 
○ Dekrit presiden 5 Juli 1959 menegaskan bahwa berlakunya kembali UUD 1945 yang berarti penetapan Pancasila sebagai dasar negara dan ideologi negara.

○ Instruksi presiden No. 12 Tahun 1968 enegaskan tentang rumusan Pancasila yang benar dan sah yang berarti Pancasila ditegaskan sebagai dasar negara dan ideologi negara.

o Ketetapan MPR o. XVIII/MPR/1998 tentang pencabutan ketetapan MPR RI No. II/MPR/1978 tentang Pedoman Penghayatan dan Pengamalan Pancasila (Eka Prasetya Pancakarsa). Kemudian tentang penegasan Pancasila sebagai dasar negara dinyatakan dalam Pembukaan UUD 1945, yaiut dasar negara dari Negara Kesatuan Indonesia harus dilaksanakan secara konsisten dalam kehidupan beregara. Bagian tak terpisahkan dari ketetapan tersebut menyatakan: "bahwa dasar negara yang dimaksud dalam ketetapan ini di dalamnhya mengandung makna sebagai ideologi nasional sebagai cita-cita dan tujuan negara."

Dari keempat poin di atas kita bisa ketahui bahwa kedudukan Pancasila sebagai dasar negara Indonesia secara hukum sangat kuat. Pertanyaan tentang bagaimana mengimplementasi Pancasila sebagai dasar negara dalam kehidupan berbangsa dan bernegara memang persoalan lain. Namun setidaknya kita telah pahami bahwa berdirinya bangsa ini sampai sekarang, pemerintah dan para politikus yang berada dijajaran kekuasaan masih mengakui dan mempertahankan Pancasila sebagai dasar negara kita yang resmi.

- Makna Pancasila sebagai dasar negara

Beberapa makna Pancasila sebagai dasar negara, antara lain Pancasila merupakan dasar sistem penyelengaraan negara, Pancasila merupakan dasar sistem pemerintahan, Pancasila merupakan sumber hukum dalam kehidupan berbangsa dan bernegara. 
Dari makna yang dijabarkan di atas, kita bisa pahami bahwa segala sesuatu yang terkait dengan penyelenggaraan negara dan kehidupan berbangsa mesti berpegang teguh pada Pancasila. Sebagai contoh, ketika kita dihadapkan pada pertanyaan tentang bagaimana menyikapi adanya kelompok minoritas yang bernama LGBTQ, sikap yang kita ambil sebagai warga negara Indonesia semestinya tidak menyalahkan nilai-nilai yang terkandung dalam Pancasila. Ketika kekayaan alam di bumi Indonesia di eksplorasi, kita harus mengambil sikap sesuai dengan nilai-nilai Pancasila. Di sini sudah jelas bahwa, kekayaan alam semestinya didistribusikan secara merata demi mewujudkan kedilan sosial bagi seluruh rakyat Indonesia, misalnya. Demikianlah makna Pancasila sebagai dasar negara Indonesia dijelaskan.

Sumber sosiologis Pancasila sebagai dasar negara

Latif (Pimpinan MPR dan Tim Kerja Sosialisasi MPR periode 2009-2014, 2013) menguraikan pokok-pokok moralitas dan haluan kebangsaan-kenegaraan menurut alam Pancasila sebagai berikut.

- Pertama, nilai-nilai ketuhanan (religiusitas) sebagai sumber etika dan Spiritualitas (yang bersifat vertical transcendental) dianggap penting sebagai fundamental etika kehidupan bernegara. Negara menurut Pancasila diharapkan dapat melindungi dan mengembangkan kehidupan beragama; sementara agama diharapkan dapat memainkan peran publik yang berkaitan dengan penguatan etika sosial. Sebagai negara yang dihuni oleh penduduk dengan multiagama dan multikeyakinan, negara Indonesia diharapkan dapat mengambil jarak yang sama, melindungi terhadap semua agama dan keyakinan serta dapat mengembangkan politiknya yang dipandu oleh nilai-nilai agama Sebagai fundamental etika-politik kehidupan bernegara dalam pergaulan dunia. Prinsip 
kebangsaan yang luas mengarah pada persaudaraan dunia yang dikembangkan melalui jalan eksternalisasi dan internalisasi.

- Kedua, nilai-nilai kemanusiaan universal yang bersumber dari hukum tuhan,hukum alam dan sifat sifat sosial (bersifat horizontal) di anggap penting sebagai fundamental etika politik kehidupan bernegara dalam pergaulan dunia. Prinsip kebangsaan yang luas mengarah pada persaudaraan dunia yang di kembangkan melalui jalan eksteenalisasi dan internalisasi.

- Ketiga, nilai-nilai etis kemanusiaan harus mengakar kuat dalam lingkungan pergaulan kebangsaan yang lebih dekat sebelum menjangkau pergaulan dunia yang lebih jauh. Indonesia memiliki prinsip dan visi kebangsaan yang kuat, bukan saja dapat mempertemukan kemajemukan masyarakat dalam Kebaruan komunitas politik bersama, melainkan juga mampu memberi kemungkinan bagi keragaman komunitas untuk tidak tercerabut dari akar tradisi dan kesejarahan masing-masing. Dalam khazanah Indonesia,Hal Tersebut menyerupai perspektif "etnosimbolis" yang memadukan antara Perspektif "modernis" yang menekankan unsur-unsur kebaruan dalam Kebangsaan dengan perspektif "primordialis" dan "perenialis" yang melihat Unsur lama dalam kebangsaan.

- Keempat,nilai ketuhanan, nilai kemanusiaan, dan nilai serta cita-cita kebangsaan itu dalam aktualisasinya harus menjunjung tinggi kedaulatan rakyat yang dipimpin oleh hikmat kebijaksanaan. Dalam prinsip musyawarah-mufakat, keputusan tidak didikte oleh golongan mayoritas atau kekuatan minoritas elit politik dan pengusaha, tetapi dipimpin oleh hikmat/ kebijaksanaan yang memuliakan daya-daya rasionalitas deliberatif dan kearifan setiap warga tanpa pandang bulu.

- Kelima, nilai ketuhanan, nilai kemanusiaan, nilai dan cita kebangsaan serta demokrasi permusyawaratan itu memperoleh artinya sejauh dalam mewujudkan keadilan sosial. 
Dalam visi keadilan sosial menurut Pancasila, yang dikehendaki adalah keseimbangan antara peran manusia sebagai makhluk individu dan peran manusia sebagai makhluk sosial, juga antara pemenuhan hak sipil, politik dengan hak ekonomi, sosial dan budaya.

Dalam visi keadilan sosial menurut Pancasila, yang dikehendaki adalah keseimbangan antara peran manusia sebagai makhluk individu dan peran manusia sebagai makhluk sosial, juga antara pemenuhan hak sipil, politik dengan hak ekonomi, sosial dan budaya. Pandangan tersebut berlandaskan pada pemikiran Bierens de Haan Soeprapto, Bahar dan Arianto, 1995: 124 yang menyatakan bahwa keadilan sosial setidak-tidaknya memberikan pengaruh pada usaha menemukan cita negara bagi bangsa Indonesia yang akan membentuk negara dengan struktur sosial asli Indonesia. Namun, struktur sosial modern mengikuti perkembangan dan tuntunan zaman sehingga dapatlah dimengerti apabila para penyusun Undang-Undang Dasar 1945 berpendapat bahwa cita negara Indonesia (de Indonesische Staatsidee) haruslah berasal dan diambil dari cita paguyuban masyarakat Indonesia sendiri.

\section{PENUTUP}

Sumber sosiologis pancasila sebagai dasar negara nilai pengembangan iptek dapat di temukan pada sikap masyarakat yang sangat memperhatikan dimesi ketuhanan dan kemanusiaan sehingga manakala iptek tidak sejalan dengan nilai ketuhanan dan kemanusiaan,biasanya terjadi penolakan. Contohnya, penolakan masyarakat atas rencana pembangunan pusat pembakit listrik tenaga nuklir di semenanjung muria di dasarkan pada kekhawatiran atas kemungkinan kebocoran pembakit listtrik 
Hal ini membuktikan bahwa masyarakat peka terhadap isu-isu ketuhanan dan kemanusiaan yang ada di balik pembangunan pusat tenaga nuklir tersebut dan kemanusiaan yang ada di balik pembangunan pusat tenaga nuklir tersebut.isu ketuhanan di kaitkan dengan di kesampingkan masyarakat manusia sebagai hamba tuhan yang maha esa dalam pembangunan iptek.artinya pembangunan fasilitas teknologi acapkali tidak melibatkan peran serta masyarakat sekitar padahal apabila terjadi dampak negatif berupa kerusakan fasilitas teknologi maka masyarakat yang akan terkena langsung akibatnya.

Yang dikehendaki adalah keseimbangan antara peran manusia sebagai makhluk individu dan peran manusia sebagai makhluk sosial, juga antara pemenuhan hak sipil, politik dengan hak ekonomi, sosial dan budaya. Pandangan tersebut berlandaskan pada pemikiran Bierens de Haan Soeprapto, Bahar dan Arianto, 1995: 124 yang menyatakan bahwa keadilan sosial setidaktidaknya memberikan pengaruh pada usaha menemukan cita negara bagi bangsa Indonesia yang akan membentuk negara dengan struktur sosial asli Indonesia. Namun, struktur sosial modern mengikuti perkembangan dan tuntunan zaman sehingga dapatlah dimengerti apabila para penyusun Undang-Undang Dasar 1945 berpendapat bahwa cita negara Indonesia (de Indonesische Staatsidee) haruslah berasal dan diambil dari cita paguyuban masyarakat Indonesia sendiri.

\section{DAFTAR PUSTAKA}

Darmini Roza dan Laurensius Arliman S Peran Pemerintah Daerah Di Dalam Melindungi Hak Anak Di Indonesia, Masalah-Masalah Hukum, Volume 47, Nomor 1, 2018.

Laurensius Arliman S, Komnas HAM dan Perlindungan Anak Pelaku Tindak Pidana, Deepublish, Yogyakarta, 2015. 
Laurensius Arliman S, Penguatan Perlindungan Anak Dari Tindakan Human Trafficking Di Daerah Perbatasan Indonesia, Jurnal Selat, Volume 4, Nomor 1, 2016.

Laurensius Arliman S, Problematika Dan Solusi Pemenuhan Perlindungan Hak Anak Sebagai Tersangka Tindak Pidana Di Satlantas Polresta Pariaman, Justicia Islamica, Volume 13, Nomor 2, 2016.

Laurensius Arliman S, Pelaksanaan Perlindungan Anak Yang Tereksploitasi Secara Ekonomi Oleh Pemerintah Kota Padang, Veritas et Justitia, Volume 2, Nomor 1, 2016.

Laurensius Arliman S, Kedudukan Ketetapan MPR Dalam Hierarki Peraturan Perundang-Undangan Di Indonesia, Lex Jurnalica, Volume 13, Nomor 3, 2016.

Laurensius Arliman S, Komnas Perempuan Sebagai State Auxialiary Bodies Dalam Penegakan Ham Perempuan Indonesia, Justicia Islamica, Volume 14, Nomor 2, 2017.

Laurensius Arliman S, Peranan Pers Untuk Mewujudkan Perlindungan Anak Berkelanjutan Di Indonesia, Jurnal Ilmu Hukum Tambun Bungai, Volume 2, Nomor 2, 2017.

Laurensius Arliman S, Mewujudkan Penegakan Hukum Yang Baik Untuk Mewujudkan Indonesia Sebagai Negara Hukum, Jurnal Hukum Doctrinal, Volume 2, Nomor 2, 2017.

Laurensius Arliman S, Participation Non-Governmental Organization In Protecting Child Rights In The Area Of Social Conflict, The 1st Ushuluddin and Islamic Thought International Conference (Usicon), Volume 1, 2017.

Laurensius Arliman S, Partisipasi Masyarakat Dalam Pembentukan Perundang-Undangan Untuk Mewujudkan Negara Kesejahteraan Indonesia, Jurnal Politik Pemerintahan Dharma Praja, Volume 10, Nomor 1, 2017, https://doi.org/10.33701/jppdp.v10i1.379.

Laurensius Arliman S, Peran Komisi Perlindungan Anak Indonesia Untuk Mewujudkan Perlindungan Anak, Jurnal Respublica Volume 17, Nomor 2, 2018.

Laurensius Arliman S, Menjerat Pelaku Penyuruh Pengrusakan Barang Milik Orang Lain Dengan Mempertimbangkan Asas Fungsi Sosial, Jurnal Gagasan Hukum, Volume 1, Nomor 1, 2019.

Laurensius Arliman S, Ilmu Perundang-Undangan Yang Baik Untuk Negara Indonesia, Deepublish, Yogyakarta, 2019.

Laurensius Arliman S, Isdal Veri, Gustiwarni, Elfitrayenti, Ade Sakurawati, Yasri, Pengaruh Karakteristik Individu, Perlindungan Hak Perempuan Terhadap Kualitas Pelayanan Komnas Perempuan Dengan Kompetensi Sumber Daya Manusia Sebagai Variabel Mediasi, Jurnal Menara Ekonomi: Penelitian dan Kajian Ilmiah Bidang Ekonomi, Volume 6, Nomor 2, 2020.

Laurensius Arliman S, Pendidikan Kewarganegaraan, Deepublish, Yogyakarta, 2020.

Laurensius Arliman S, Makna Keuangan Negara Dalam Pasal Pasal 23 E Undang-Undang Dasar 1945, Jurnal Lex Librum, Volume 6, Nomor 2 Juni 2020, http://dx.doi.org/10.46839/11jih.v6i2.151. 
Laurensius Arliman S, Kedudukan Lembaga Negara Independen Di Indonesia Untuk Mencapai Tujuan Negara Hukum, Kertha Semaya Journal Ilmu Hukum, Volume 8, Nomor 7, 2020.

Laurensius Arliman S, Pelaksanaan Assesment Oleh Polres Kepulauan Mentawai Sebagai Bentuk Pelaksanaan Rehabilitasi Bagi Pecandu Dan Korban Penyalahgunaan Narkotika, Jurnal Muhakkamah, Volume 5, Nomor 1, 2020.

Laurensius Arliman S, Aswandi Aswandi, Firgi Nurdiansyah, Laxmy Defilah, Nova Sari Yudistia, Ni Putu Eka, Viona Putri, Zakia Zakia, Ernita Arief, Prinsip, Mekanisme Dan Bentuk Pelayanan Informasi Kepada Publik Oleh Direktorat Jenderal Pajak, Volume 17, No Nomor, 2020.

Larensius Arliman S, Koordinasi PT. Pegadaian (Persero) Dengan Direktorat Reserse Narkoba Polda Sumbar Dalam Penimbangan Barang Bukti Penyalahgunaan Narkotika, UIR Law Review, Volume 4, Nomor 2, 2020, https://doi.org/10.25299/uirlrev.2020.vol4(1).3779.

Laurensius Arliman S, Tantangan Pendidikan Kewarganegaraan Pada Revolusi 4.0, Ensiklopedia Sosial Review, Volume 2, Nomor 3, 2020.

Muhammad Afif dan Laurensius Arliman S, Protection Of Children's Rights Of The Islamic And Constitutional Law Perspective Of The Republic Of Indonesia, Proceeding: Internasional Conference On Humanity, Law And Sharia (Ichlash), Volume 1, Nomor 2, 2020.

Otong Rosadi danLaurensius Arliman S, Urgensi Pengaturan Badan Pembinaan Idelogi Pancasila Berdasarkan Undang-Undang Sebagai State Auxiliary Bodies yang Merawat Pancasila dalam Perspektif Hak Asasi Manusia, Prosiding Konferensi Nasional Hak Asasi Manusia, Kebudayaan dan Tujuan Pembangunan Berkelanjutan Indonesia pada Masa Pandemi Covid19: Tantangan untuk Keilmuan Hukum dan Sosial Volume 1, Universitas Pancasila, Jakarta, 2020. 